\title{
HUBUNGAN KARAKTERISTIK PERAWAT DENGAN PELAKSANAAN ASUHAN KEPERAWATAN SPIRITUAL ISLAMI DI RUANG RAWAT INAP DEWASA RUMAH SAKIT KABUPATEN BANDUNG
}

\author{
Inggriane Puspita Dewi, Rahmat,Suryadi Alamsyah \\ Sekolah Tinggi IImu Kesehatan 'Aisyiyah Bandung, JI.KH.Ahmad Dahlan dalam no 6, (022) 73052699 \\ Email: ine.stikes12@gmail.com
}

\begin{abstract}
ABSTRAK
Kesenjangan antara pemenuhan kebutuhan spiritual oleh perawat dengan yang diterima oleh pasien rawat inap dewasa di rumah sakit Kabupaten Bandung ini mendorong sebuah penelitian dengan tujuan menganalisis implementasi asuhan keperawatan spiritual muslim di ruang rawat inap dewasa. Desain penelitian yang digunakan dalam penelitian ini adalah deskriptif korelatif, dengan pendekatan Cross Sectional sampel dalam penelitian ini adalah semua perawat pelaksana yang melakukan tindakan langsung kepada pasien yaitu sebanyak 39 orang dan pasien yang telah dirawat di ruangan $\geq 3$ hari. Teknik pengambilan data dengan menggunakan kuesioner bagi perawat dan pasien, selain itu peneliti melakukan observasi terhadap dokumentasi asuhan spiritual Islami yang telah dilakukan perawat serta wawancara pada perawat. Hasil penelitian menunjukan pelaksanaan spiritual care Islami di ruang rawat inap dewasa ini, sebagian besar belum terlaksana (53\%), data didukung oleh pernyataan pasien (68\%) mengatakan kurang mendapatkan asuhan spiritual dari perawat serta aspek pendokumentasian yang kurang (33\%) untuk pengkajian dan penegakan diagnosa keperawatan, sementara untuk perencanaan, implementasi dan evaluasi $100 \%$ tidak terdokumentasi. Terdapat hubungan antara jenis kelamin, pelatihan dan lama kerjaperawat dengan pelaksanaan asuhan keperawatan spiritual Islami (nilai $P=0,000$ ) dan terdapat hubungan jenis kelamin dan lama kerja perawat dengan pendokumentasian asuhan keperawatan spiritual Islami dengan (nilai P 0,000 ).
\end{abstract}

Kata kunci : :asuhankeperawatan spiritual islami;perawat; dokumentasi

\section{THE CORRELATION BETWEEN NURSE CHARACTERISTICS AND THE IMPLEMENTATION OF ISLAMIC SPIRITUAL NURSING CARE IN ADULT WARD OF BANDUNG DISTRICT HOSPITAL}

\begin{abstract}
The gap between the fulfillment of spiritual needs by nurses and those received by adult inpatients room at Bandung Regency hospital encourages a study with the aim of analyzing the implementation of Muslim spiritual nursing care in adult inpatients. The research design used in this study was descriptive correlative, with a cross sectional approach. The sample in this study were all nurses who took direct action on the patient, as many as 39 people and patients who had been treated in the room $\geq 3$ days. The data collection technique used a questionnaire for nurses and patients. In addition, the researcher made observations on the documentation of Islamic spiritual care that had been carried out by nurses and interviews with nurses. The results of the study show that the implementation of Islamic spiritual care in inpatient rooms today has not largely been implemented (53\%), the data is supported by statements of patients (68\%) saying they do not get spiritual care from nurses and lack of documentation (33\%) for assessment and enforcement of nursing diagnoses, while for planning, implementation and evaluation they are 100\% undocumented. There is a relationship between gender, training experience and length of work of nurses with the implementation of Islamic spiritual nursing care (value $P=0.000$ ) and there is a relationship between gender and length of work of nurses with documentation of Islamic spiritual nursing care with ( $P$ value 0,000$)$..
\end{abstract}

Keywords: islamicspiritual nursing care;nurse; documentation

Jurnal SMART Keperawatan is licensed under a Creative Commons Attribution-ShareAlike 4.0 International License 


\section{LATAR BELAKANG}

World Health Organization (WHO) menyatakan definisi rumah sakit adalah bagian integral dari suatu organisasi sosial dan kesehatan dengan fungsi menyediakan pelayanan paripurna (Komprehensif), penyembuhan penyakit (Kuratif) dan pencegahan penyakit (Preventif) kepada masyarakat (Pangerapan, Palandeng, \& Rattu, 2018). Definisi rumah sakit di Indonesia dinyatakan dalam Undang-Undang Kesehatan RI No. 44 Tahun 2009 tentang rumah sakit, yaitu institusi pelayanan kesehatan yang menyelenggarakan pelayanan kesehatan perorangan secara paripurna melalui pelayanan rawat inap, rawat jalan, dan gawat darurat.

Rumah sakit di Indonesia dimiliki oleh pemerintah maupun swasta, menurut data dari Kementrian Kesehatan tahun 2016 jumlah rumah sakit yang ada di Indonesia adalah sebanyak 2.601 yang tersebar diseluruh Indonesia dan sebanyak 328 rumah sakit berada di provinsi Jawa Barat. Rumah sakit tersebut memiliki tipe-tipe tersendiri dan pola pelayannya masing-masing (Kemenkes RI, 2019). Di kota Bandung sendiri terdapat rumah sakit yang bernuansa Islami dan sudah menerapkan pelayanan Islami sebagai standar dalam memberikan pelayanan asuhan keperawatannya, salah satunya adalah rumah sakit umum daerah di Kabupaten Bandung, sebagaimana yang tertulis dalam salah satu misi rumah sakit yaitu, "Memberikan pelayanan kesehatan yang bernuansa Islami dengan unggulan pelayanan kesehatan industri, kesehatan ibu dan anak, dan kesehatan lansia"(Al-Ihsan, 2017) .

Visi dan misi rumah sakit dalam memberikan pelayanan kesehatan yang bernuansa Islami, mendorong rumah sakit untuk mewujudkan pelayanan secara komprehensif dalam memenuhi kebutuhan pasien baik biologis, psikologis, sosial maupuan spiritual. Pentingnya aspek spiritual dalam menunjang pengobatan aspek lainnya yaitu biologis dan psikososial tidak dapat ditawartawar lagi, karena pasien di rumah sakit terutama pasien rawat inap bukan hanya menderita berbagai penyakit fisik akan tetapi mereka juga mengalami berbagai tekanan dan gangguan mental spiritual dari yang ringan sampai yang berat sebagai akibat dari penyakit yang dideritanya. Penelitian-penelitian telah banyak dilakukan tentang bagaimana pengaruh pemberian asuhan spiritual terhadap kesehatan, seperti menurunkan stress (Dadfar, Bahrami, Noghabi, \& Askari, 2016). Mayoritas penelitian menunjukkan bahwa perawatan spiritual memiliki efek dalam meningkatkan kualitas hidup dan kesejahteraan spiritual di antara pasien (Chen, Lin, Yan, $\mathrm{Wu}, \& \mathrm{Hu}$, 2018), meningkatkan koping religius (I. P. Dewi \& Widiyanti, 2018), menurunkan tekanan darah (Nurhakim, Dewi, \& Rohmah, 2018) dan meningkatkan kesehatan mental (Inggriane Puspita Dewi \& Siti Ulfah Rifa'atul Fitri, 2020) bahkan (Heidari \& Yoosefee, 2016) menyatakan bahwa pemberian asuhan spiritual menjadi hal yang mendasar dalam model pelayanan kesehatan, alasannya karena kesehatan spiritual dapat mempengaruhi sikap dan prilaku individu dalam kehidupannya termasuk kesehatan fisik dan psikososialnya.

Pemberian asuhan spiritual pada pasien juga dapat menjadi salah satu indikator yang mendukung kepuasaan pasien yang dirawat di rumah sakit (Nurdina \& Putra, 2016; Sjattar \& Hadju, 2019), namun kenyataannya, pemenuhan kebutuhan spiritual oleh perawat kurang terpenuhi, karena persepsi perawat dalam memenuhi kebutuhan spiritual baru sebatas memenuhi kebutuhan ibadah pasien saja (R. R. Dewi \& Dewi, 2016), serta perawat merasa tidak memiliki waktu yang cukup untuk memberikan asuhan spiritual (Estetika \& Jannah, 2016).Persepsi perawat terhadap nilai spiritual berkontribusi terhadap perkembangan kemampuan professional untuk memberikan asuhan spiritual. Asuhan spiritual seharusnya meliputi proses pengkajian, penegakan diagnosis spiritual, perencanaan, implementasi dan evalusi dalam memenuhi kebutuhan aktifitas religius dan spiritual pasien (I. P. Dewi \& Anugerah, 2020). Aktifitas religius meliputi memenuhi kebutuhan ibadah pasien serta aktifitas spiritual meliputi kegiatan perawat dalam membimbing pasien menemukan harapan, makna sakit, kekuatan cinta serta dukungan social (Berman, Snyder, \& Frandsen, 2015). 
Hasil studi pendahuluan di rumah sakit tempat penelitian ini, melalui hasil wawancara kepada kepala instalasi ruangan rawat inap dewasa menyebutkanbahwadirumahsakit ini sudahmenerapkanasuhanspiritualdiruangan diantaranya seperti membantu berdoa, berzikir, bersuci, ibadah shalat dan membimbing pada saat klien mengalami Syakaratulmaut. Pelatihan spiritual care pernah dilakukan di rumah sakit ini, namun topik kajian meliputi fiqh ibadah bagi pasien di rumah sakit, bimbingan ibadah (tadzkiroh), serta pengurusan jenazah, belum mengarah pada pelatihan spiritual care secara utuh, latar belakang pendidikan perawat masih didominasi oleh Diploma Keperawatan, serta rata-rata memiliki pengalaman kerja lebih dari lima tahun.

Dari data-data tersebut dapat disimpulkan bahwa asuhan keperawatan spiritual yang diberikan baru sebatas pemenuhan kebutuhan aspek ibadah, belum mencakup keseluruhan proses keperawatan mulai dari pengkajian hingga evaluasi. Studi pendahuluan juga dilakukan kepada pasien, sepuluh pasien menyatakan pernah dibimbing shalat oleh perawat, diingatkan untuk berdoa dan bersabar, namun pasien menyatakan perawat jarang menanyakan keadaan batinnya atau menanyakan kondisinya setelah dibimbing sholat, atau ada tindakan khusus untuk meningkatkan harapan atau menenangkan keadaan batinnya.

Berdasarkan hal tersebut, maka bagaimana hubungan karakteristik perawat dengan pelaksanaan asuhan keperawatan spiritual Islami di rumah sakit ?Tujuan penelitian ini untuk menganalisis hubungan karakteristik perawat dengan pelaksanaan asuhan keperawatan spiritual Islami, termasuk pendokumentasian asuhannya di ruang rawat inap dewasa agar kualitas asuhan spiritual baik di lahan praktik

\section{METODE}

Jenis penelitian yang digunakan adalah deskriptif eksploratif.Populasi dalam penelitian adalah perawat bukan kepala ruangan yang bertugas di ruang rawat inap dewasa. Pengambilan sampel dalam penelitian ini menggunakan total samplingsebanyak 39 responden perawat pelaksana, dan untuk teknik pengumpulan data dilakukan dengan cara penyebaran kuesioner atau angket kepada perawat yang bertugas di ruangan dan juga kuesioner atau angket kepada pasien yang sedang dirawat di ruangan tersebut $\geq 3$ hari, sebanyak 39 orang. Uji validitas angket untuk perawat di rumah sakit yang memiliki kriteria yang sama dengan tempat penelitian, kepada 30 orang perawat. Angket untuk perawat menggunakan skala likert mencakup pengkajian (7), diagnosis keperawatan spiritual (5), perencanaan keperawatan (5), intervensi (5), evaluasi (3). Sedangkan kuesioner yang akan diberikan kepada pasien terdiri dari 15 pertanyaan, terdiri dari pengkajian (4), intervensi (8) dan evaluasi (3). Reablilitas kuesioner untuk perawat sebesar 0.715 dan kuesioner untuk pasien di dapatkan hasil reabilitas sebesar 0,676 dari hasil tersebut maka kedua kuesioner tersebut dinyatakan reliabel.Selain itu peneliti juga melakukan observasi terhadap pendokumentasian asuhan keperawatan yang dilakukan oleh perawat pelaksana di ruangan rawat inap dewasa serta melakukan wawancara kepada beberapa perawat dalam ruangan tersebut.

Tehnik analisis data dilakukan dengan mengumpulkan seluruh data angket yang telah diperiksa kelengkapannya, untuk angket kompetensi umum digunakan nilai rentang 1 sampai dengan 4 , dan untuk lembar obervasi jika dilakukan diberi nilai 1 dan jika tidak dilakukan diberi nilai 0 (nol). Selanjutnya dilakukan analisa data univariate dengan menggunakan persentase, ditabulasi dan ditafsirkan dengan kriteria objektif sesuai kaidah yang berlaku.Analisa data bivariate menggunakan uji kontingensi, karena data berskala nominal untuk asosiasi antara karaktersitik responden dengan pelaksanaan dan dokumentasi asuhan spiritual Islami. 


\section{HASIL}

Karakteristik responden dapat dilihat pada tabel dibawah ini :

Tabel 1. Distribusi frekuensi karakteristik responden $(n=39)$

\begin{tabular}{lcccc}
\hline \multicolumn{1}{c}{ Karakteristik } & \multicolumn{2}{c}{ Perawat } & \multicolumn{2}{c}{ Pasien } \\
\cline { 2 - 5 } & $\mathbf{n}$ & $\mathbf{( \% )}$ & $\mathbf{N}$ & $\mathbf{( \% )}$ \\
\hline Jenis kelamin & & & & \\
1. Laki-laki & 14 & $36 \%$ & 23 & $59 \%$ \\
2. perempuan & 25 & $64 \%$ & 26 & $67 \%$ \\
\hline Pendidikan terakhir & & & & \\
1. SD & & & 19 & $49 \%$ \\
2. SMP & & & 20 & $51 \%$ \\
3. SMA & & & 0 & 0 \\
4. Diploma & 37 & $95 \%$ & 0 & 0 \\
5. Sarjana & 2 & $5 \%$ & 0 & 0 \\
\hline Riwayat pelatihan & & & & \\
spiritual care & & & & \\
1. Pernah & 24 & $62 \%$ & & \\
2. Tidak pernah & 19 & $38 \%$ & & \\
\hline Lama Kerja & & & \\
1. <5 tahun & 12 & $31 \%$ & \\
2. $\geq 5$ tahun & 27 & $69 \%$ & \\
\hline
\end{tabular}

Tabel 1 menunjukan responden perawat didominasi oleh perempuan (64\%) dengan level pendidikan terbanyak Diploma III keperawatan (95\%) serta sebagian besar (62\%) pernah mengikuti kegiatan pelatihan spiritual care, sementara karakteristik pasienmenunjukan responden pasien didominasi oleh laki-laki (67\%) dengan level pendidikan terbanyak SMP (51\%).Data univariate berikutnya adalah distribusi frekuensi pelaksanaan asuhan keperawatan spiritual Islam ditinjau dari perawat sebagai pelaksana, pasien sebagai penerima asuhan dan hasil observasi dokumentasi keperawatan pada asuhan spiritual Islami.Semua data disajikan pada gambar 1 s.d 3 dibawah ini.

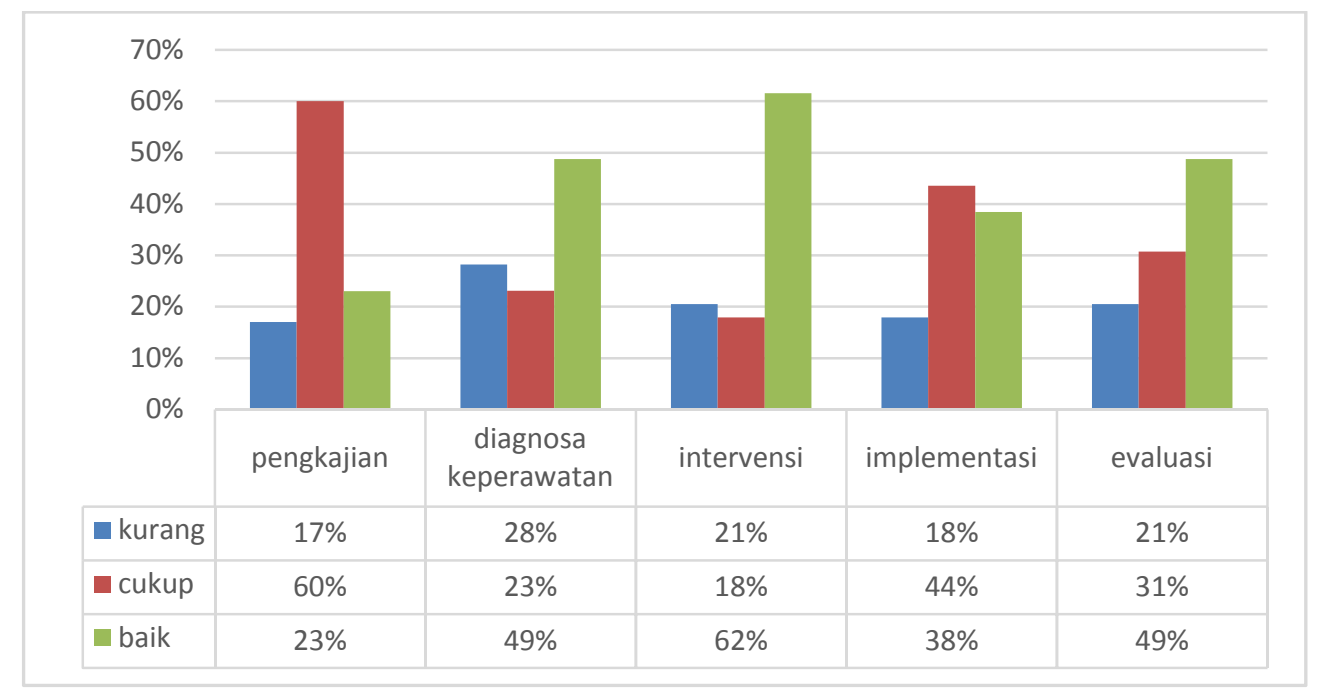

\section{Gambar 1. Pelaksanaan spiritual care yang dipersepsikan oleh perawat}

Gambar 1 menunjukan pendapat perawat tentang pelaksanaaan asuhan keperawatan spiritual Islami pada aspek pengkajian dipersepsikan sudah cukup terlaksana (60\%), mampu menegakkan diagnosa keperawatan spiritual (49\%), membuatperencanaan tindakan (intervensi) dengan baik (62\%), hampir sebagian perawat melaksanakan intervensi spiritual (44\%) serta melakukan evaluasi tindakan keperawatan spiritual (49\%). 


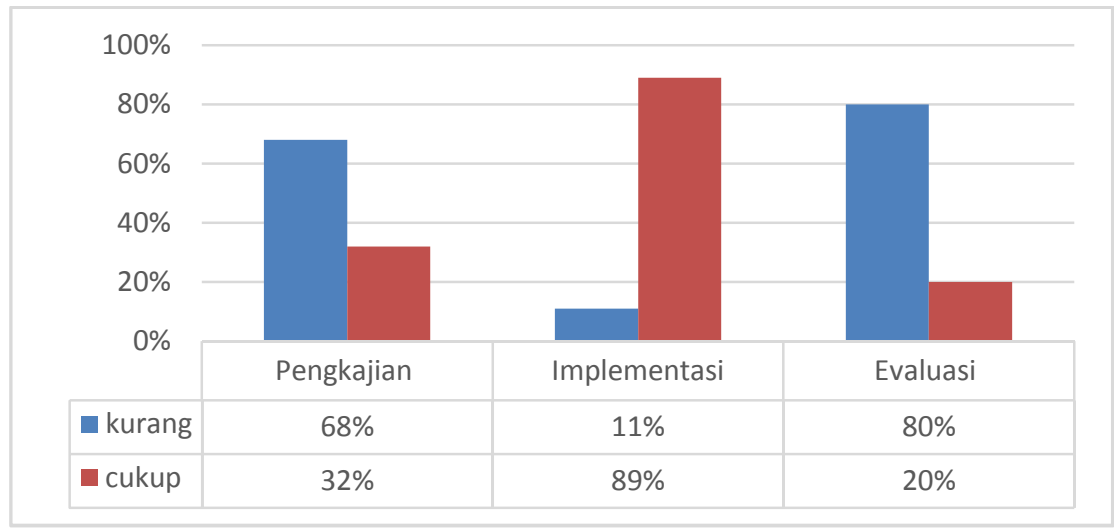

Gambar 2. Aspek pelaksanaan spiritual care yang diterima oleh pasien

Gambar 2 menunjukan bahwa sebagian besar pasien masih merasakan perawat kurang dalam hal mengkaji kondisi spiritual (68\%), namun hampir seluruh pasien (89\%) mendapatkan intervensi spiritual dari perawat, sementara hampir semua pasien (80\%) menyatakan perawat tidak menanyakan kembali kondisi spiritual pasien setelah diberikantindakan

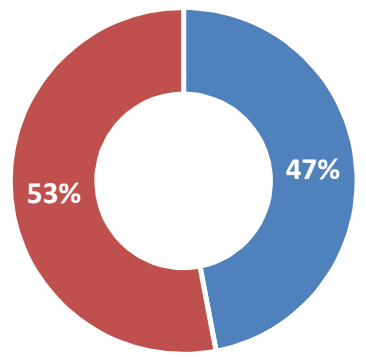

- terlaksana

- tidak terlaksana

Gambar 3. Pelaksanaan spiritual care yang diterima oleh pasien secara keseluruhan

Gambar 3 menunjukan secara keseluruhan, hampir sebagian perawat (47\%) memenuhi kebutuhan spiritual pasien, namun sebanyak 53\% pemenuhan kebutuhan spiritual belum terpenuhi.

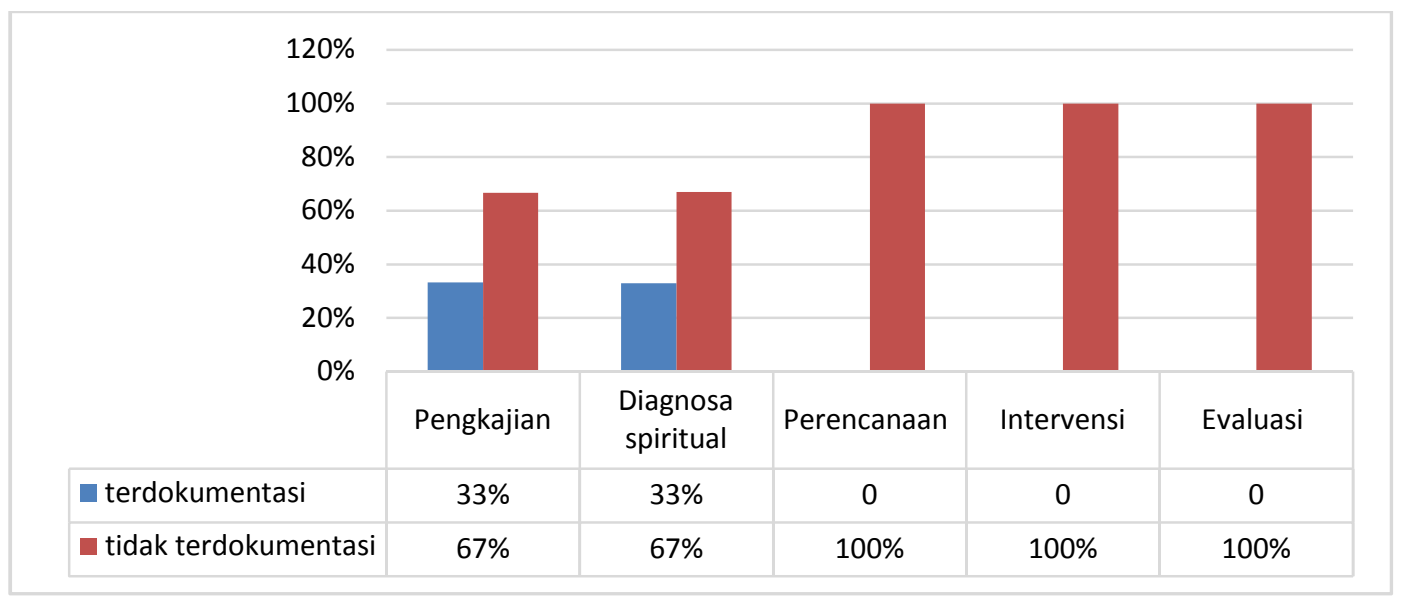

Gambar 4. Dokumentasi pelaksanaan spiritual care Islami oleh perawat 
Gambar 4 menunjukan hasil observasi terhadap aspek pendokumentasian pelaksanaan asuhan keperawatan spiritual Islam di ruang rawat inap dewasa, sebagain besar aspek pengkajian dan diagnose keperawatan spiritual terdokumentasi dengan baik, namun pada aspek perencanaan, tindakan dan evaluasi tidak terdokumentasi secara keseluruhan (100\%).Analisis bivariate dalam penelitian ini, melihat korelasi antara karakteristik responden (pendidikan, pelatihan spiritual care dan lama kerja) dengan pelaksanaan asuhan spiritual Islam.Hasil analisis, disajikan pada tabel dibawah ini.

Tabel 3. Hasil uji kontingensi karakteristik responden dengan pelaksanaan asuhan keperawatan spiritual Islami

\begin{tabular}{lcc}
\hline \multicolumn{1}{c}{ Variabel } & $\begin{array}{c}\text { Nilai } \\
\text { Signifikansi (P) }\end{array}$ & $\begin{array}{c}\text { Nilai Koefisien } \\
\text { korelasi }(\mathbf{r})\end{array}$ \\
\hline Jenis kelamin & 0,000 & 0,693 \\
Pendidikan & 0,117 & 0,251 \\
Lama Kerja & 0,000 & 0,854 \\
Pelatihan & 0,000 & 0,617 \\
spiritual care & & \\
\hline
\end{tabular}

Tabel 3 menunjukan, terdapat hubungan antara jenis kelamin, lama kerja serta keikusertaan pelatihan spiritual care terhadap pelaksanaan asuhan keperawatan Islami di ruang rawat inap dewasa, namun tingkat pendidikan tidak memiliki hubungan dengan pelaksanaan asuhan keperawatan Islami. Dengan nilai koefisien korelasi yang kuat untuk hubungan jenis kelamin dengan pelaksanaan asuhan spiritual Islami dan sangat kuat pada karakteristik lama kerja dan pelatihan spiritual care.

Tabel 4.Hasil uji kontingensi karakteristik responden dengan dokumentasi asuhan keperawatan spiritual Islami

\begin{tabular}{lcc}
\hline \multicolumn{1}{c}{ variabel } & $\begin{array}{c}\text { Nilai } \\
\text { Signifikansi } \\
(\mathbf{P})\end{array}$ & $\begin{array}{c}\text { Nilai Koefisien } \\
\text { korelasi }(\mathbf{r})\end{array}$ \\
\hline Jenis kelamin & 0,001 & 0,451 \\
Pendidikan & 0,578 & 0,089 \\
Lama Kerja & 0,000 & 0,499 \\
Pelatihan & 0,058 & 0,290 \\
spiritual care & & \\
\hline
\end{tabular}

Tabel 4 menunjukan, terdapat hubungan antara jenis kelamin dan lama kerja dengan dokumentasi asuhan keperawatan Islami di ruang rawat inap dewasa, namun tingkat pendidikan dan pelatihan spiritual care tidak memiliki hubungan dengan dokumentasi asuhan keperawatan Islami.Dengan nilai koefisien korelasi yang sedang untuk hubungan jenis kelamin dan lama kerja.

\section{PEMBAHASAN}

Hasil penelitian diatas menunjukan pelaksanaan asuhan keperawatan Islami yang dipersepsikan perawat dengan kenyataan yang diterima pasien berbeda, begitu pula dengan hasil observasi dokumentasi asuhan keperawatan spiritual Islami yang dilaksanakan oleh perawat. Dari hasil penelitian, sebagian besar perawat (60\%) menyatakan sudah melakukan pengkajian spiritual dan membuat perencanaan asuhan keperawatan spiritual (62\%), namun sebagian besar pasien (68\%) menyatakan perawat jarang menanyakan keadaan spiritualnya (pengkajian) dan sebagian kecil pasien (11\%) yang mendapatkan tindakan spiritual dari perawat, serta sebagian besar pasien (80\%) menyatakan perawat tidak menanyakan kembali keadaan pasien setelah diberi tindakan spiritual oleh perawat (evaluasi).

Hampir setengahnya dari perawat (49\%) yang menuliskan diagnosis keperawatan spiritual serta evaluasi tindakan (49\%) pada asuhan spiritual Islami, namun hanya 38\% yang menyatakan baik dalam hal memberikan (implementasi) asuhan spiritual Islami pada pasiennya. Data tersebut berbeda dengan hasil observasi peneliti pada catatan pasien, dimana hanya sebagian kecil (33\%) dari aspek pengkajian dan diagnosis keperawatan spiritual yang terdokumentasi, selebihnya untuk aspek perencanaan, implementasi dan evaluasi tidak tercatat dalam catatan pasien. Hasil wawancara kepada perawat pelaksana tentang kesulitan dalam memberikan asuhan spiritual Islami ini adalah perawat seringkali lebih fokus pada tindakan-tindakan rutinitas untuk kebutuhan fisik pasien, format asuhan spiritual Islami belum terintegrasi ke dalam catatan pasien, sehingga membutuhkan waktu yang 
lebih untuk melakukan pencatatan, walaupun perawat berupaya melakukan implementasi memenuhi kebutuhan spiritual saat melakukan tindakan ke pasien. Perawat juga menyatakan belum pernah mempraktikan secara utuh tentang pengkajian spiritual, namun lebih fokus pada pengkajian ibadah pasien.

Penelitian ini sejalan dengan Rene van Leeuwen, yang menemukan fakta adanya kesenjangan antara apa yang diharapkan perawat dalam teori dan apa yang sebenarnya dipraktikkan. Hal ini menimbulkan pertanyaan tentang bagaimana tugas perawatan spiritual dalam keperawatan dapat menjadi lebih jelas, dan tingkat keahlian yang harus diharapkan dari perawat(Van-Leeuwen, 2016).

Hasil penelitian secara keseluruhan dari pelaksanaan asuhan keperawatan spiritual Islami ini, hampir sebagian besar perawat (47\%) melaksanakan asuhan spiritual Islami pada pasiennya, meliputi pengkajian, perencanaan dan implementasi, namun aspek yang terdokumentasi sebagian kecil saja dari pengkajian dan penegakan diagnosis keperawatan. Karakteristik pasien yang diberikan asuhan keperawatan spiritual Islami di ruangan rawat inap dewasa ini, sebagian besar adalah laki-laki (59\%), sementara perawat yang bertugas sebagian besar perempuan (67\%), lihat tabel 1 , sesuai dengan hasil penelitian, bahwa jenis kelamin berhubungan dengan pelaksanaan asuhan spiritual Islami (tabel 3), hal ini menunjukan pelaksanaan asuhan spiritual Islami dipengaruhi oleh jenis kelamin pelaksana pemberi asuhan dan jenis kelamin pasien. Dalam Islam, pemberian asuhan spiritual, perlu mempertimbangkan jenis kelamin pasien(Hanin Hamjah, Shakirah Mat Akhir, Ismail, Ismail, \& Mohd Arib, 2017) sehingga asuhan spiritual Islami dapat terlaksana dengan baik dan sesuai tuntutan syariat Islam.

Hasil penelitian berikutnya, menyatakan bahwa terdapat hubungan positif $(r=0,617)$ antara pelatihan spiritual care dengan pelaksanaan asuhan spiritual Islami di ruang rawat inap dewasa. Hasil wawancara kepada perawat, menyatakan pemberian pelatihan spiritual care yang didapatkan perawat meliputi kajian tentang fiqh ibadah di rumah sakit, bimbingan ibadah pada pasien di rumah sakit, perawatan pasien menjelang ajal dan pengurusan jenazah. Pelatihan spiritual care Islami secara komprehensif sesuai alur proses keperawatan (pengkajian, penegakan diagnosa keperawatan, perencanaan, implementasi dan evaluasi) belum pernah didapatkan. Hasil penelitian ini sejalan dengan penelitian Bakir et all, yang menyatakan, minimnya perawat dalam melaksanakan asuhan spiritual care di ruang ICU karena pengetahuan dan keterampilan perawat dalam memenuhi kebutuhan tersebut masih kurang, pelatihan menjadi salah satu faktor untuk meningkatkan kemampuan dan persepsi perawat dalam pemberian asuhan keperawatan spiritual (Bakir, Samancioglu, \& Kilic, 2017). Pernyataan senada diungkapkan oleh Anisa, 2018, dalam penelitiannya, menemukan $50 \%$ perawat memiliki kompetensi yang rendah dalam memberikan asuhan spiritual pada pasien kanker, sehingga pelatihan tentang spiritual care menjadi hal yang penting di rumah sakit, untuk peningkatan kompetensi perawat dalam asuhan spiritual (Anisa, Erika, \& Rachmawaty, 2018). Penelitian (R. R. Dewi \& Dewi, 2016) tentang persepsi perawat dalam pemberian asuhan keperawatan spiritual, menemukan hasil penelitian, pemberian asuhan spiritual pada pasien baru sebatas pemberian tadzkirah (bimbingan ibadah pada pasien).

Hubungan positif antara lama kerja dengan pelaksanaan asuhan spiritual Islami, menunjukan, semakin lama perawat memiliki masa kerja, maka pelaksanaan spiritual care Islami dapat dilaksanakan. Rumah sakit tempat peneliti melakukan penelitian, senantiasa rutin megadakan kajian ke-Islaman sebagai bagian dari pembinaan keryawan, hal ini dinyatakan oleh perawat saat wawancara pada studi pendahuluan.Perawat yang memiliki masa kerja yang lama, memiliki kesempatan mengikuti kegiatan pembinaan yang bersifat wajib ini, untuk meningkatkan kesadaran spiritual perawat. Atkinson, 2015 menyatakan bahwa ajaran dan praktik Islam memiliki pengaruh besar pada perawat muslim. Para 
perawat dalam penelitian Atkinson ini melihat setiap aspek kehidupan profesional dan pribadi mereka dibentuk dan dipengaruhi oleh keyakinan dan praktik agama mereka, mereka melihat ajaran agama memengaruhi semua hubungan.Sistem nilai Islami seperti itu memiliki implikasi untuk kepuasan pasien, komitmen dalam pekerjaan dan hubungan kolegial yang positif. Kepercayaan yang kuat pada imbalan spiritual cenderung membuat beban dalam pekerjaan dipandang lebih ringan (Atkinson, 2015).

Aspek pendokumentasian asuhan keperawatan spiritual dalam penelitian ini, menunjukan sebagian besar aspek dalam proses keperawatan tidak terdokumentasi. Hasil penelitian menunjukan adanya hubungan positif lama kerja perawat dan jenis kelamin dengan pendokumentasian asuhan keperawatan spiritual Islami di rumah sakit ini. Kapasitas ruang rawat inap dewasa dengan BOR diatas $85 \%$, serta variasi kasus yang dimiliki pasien dan jumlah tenaga perawat yang kurang dalam pandangan perawat, membuat perawat seringkali lebih mengutamakan aspek pendokumenasian pada unsur keluhan fisik pasien, disamping itu, belum adanya sistem pendokumentasian yang efektif untuk asuhan spiritual Islam ini, yang tertuang dalam sistem, baru aspek pengkajian ibadah pasien (tadzkirah) dan perencanaan. Penelitian Bakir, 2017 menyatakan, hampir setengah dari perawat menyatakan hambatan untuk penerapan perawatan spiritual karena jumlah pasien yang berlebihan untuk satu perawat, jumlah pasien menyebabkan peningkatan beban kerja sehingga perawat lebih mengutamakan aspek pemenuhan kebutuhan dasar pasiendi rumah sakit (Bakir et al., 2017). Penelitian lain menemukan fakta bahwa kurangnya pendokumentasian asuhan keperawatan disebabkan oleh kekurangan personel $(72,7 \%)$, kurangnya waktu $(57,1 \%)$ dan kelelahan $(54,5 \%)$ dilaporkan sebagai yang paling penting. Di area bangsal, faktorfaktor seperti peningkatan jumlah pasien $(70,1$ $\%)$ dan volume tugas yang tinggi di bangsal $(62,3 \%)$ adalah yang paling penting. Di bidang yang terkait dengan manajemen keperawatan, kurangnya hukuman dan sistem penghargaan
$(39,5 \%)$ dan kurangnya pemantauan dan evaluasi yang berkelanjutan $(35,1 \%)$ adalah yang paling penting (Jeihooni \& Seyyed Hannan, 2016).

Pemberian asuhan keperawatan Islami, bagi pasien muslim menjadi sebuah keharusan, jika dilihat dari teori kebutuhan dasar manusia menurut Iman Asy-Syatibi. Imam Asy-Syatibi menyebutkan dalam Maqasid Syariah, bahwa memelihara agama, jiwa dan akal manusia merupakan kebutuhan mendasar yang wajib dipenuhi oleh setiap mukmin (I. P. Dewi \& Anugerah, 2020) Pemberian asuhan keperawatan spiritual Islami memberikan tujuan utama mengarahkan pasien pada kehidupan yang baik (hayatan thayiban) dan hati yang tenang(qolbun salim) (Alimohammadi \& Taleghani, 2015; Nasr, 2013). Dalam pelaksanaanya, perawat perlu dibekali kompetensi pengetahuan dan keterampilan untuk memenuhi kebutuhan spiritual pasien(Anisa et al., 2018; Frouzandeh, Aein, \& Noorian, 2015; Van-Leeuwen, 2016), baik di level pendidikan keperawatan maupun di rumah sakit(Marzband, Hosseini, \& Hamzehgardeshi, 2016; Paal, Roser, \& Frick, 2014), sebagai bentuk upgrading kemampuan perawat dalam pemberian intervensi spiritual berbasis nilai-nilai Islami.

Asuhan keperawatan merupakan sebuah proses (Berman et al., 2015), sehingga siklus proses keperawatan, memudahkan perawat dalam aspek tanggung jawab dan tanggung gugat perawat dalam melaksanakan tugasnya, maka dokumentasi menjadi hal yang sangat penting dalam keperawatan sebagai bagian dari aspek legal etik perawat terhadap pasien dan profesinya (Andualem et al., 2019; Jeihooni \& Seyyed Hannan, 2016). Dokumentasi asuhan spiritual Islami, masih jarang dilakukan, padahal aspek dokumentasi memudahkan perawat dalam menentukan langkah selanjutnya untuk memenuhi kebutuhan spiritual pasien yang dirawatnya.

\section{KESIMPULAN DAN SARAN}

Hasil penelitian menunjukan terdapat hubungan antara jenis kelamin, lama kerja serta keikusertaan pelatihan spiritual care terhadap pelaksanaan asuhan keperawatan 
Islami di ruang rawat inap dewasa, latar belakang pendidikan perawat tidak memiliki hubungan dengan pelaksanaan asuhan keperawatan spiritual, selain itu penelitian menunjukan hasil terdapat hubungan antara jenis kelamin dan lama kerja dengan dokumentasi asuhan keperawatan Islami di ruang rawat inap dewasa, namun tingkat pendidikan dan pelatihan spiritual care tidak memiliki hubungan dengan dokumentasi asuhan keperawatan Islami. Sebaiknya instansi rumah sakit mengadakan pelatihan spiritual carelslami untuk meningkatkan kompetensi perawat dalam pemberian asuhan spiritual yang meliputi pengkajian, penegakan diagnosa spiritual, perencanaan, implementasi dan evaluasi. Serta penelusuran secara detail tentang hambatan pelaksanaan dan dokumentasi spiritual care Islami di rumah sakit ini serta penelitian tentang dampak pelatihan spiritual care islami terhadap peningkatan kompetensi perawat dalam pemberian asuhan spiritual di rumah sakit Islam.

\section{REFERENSI}

Al-Ihsan. (2017). Visi Misi Rumah Sakit Umum Daerah Al-Ihsan. Retrieved from http://rsudalihsan.jabarprov.go.id/page/41 5-VISI-MISI

Alimohammadi, N., \& Taleghani, F. (2015). Health and healthy human being in Islamic thought: Reflection on application for the nursing concept - A philosophical inquiry. Journal of Education and Health Promotion, 4, 73. https://doi.org/10.4103/2277-9531.171786

Andualem, A., Asmamaw, T., Sintayehu, M., Liknaw, T., Edmealem, A., Bekalu, \& Gedfew3, B. and M. (2019). Knowledge, attitude, practice and associated factors towards nursing care documentation among nurses. Clinical Journal Nursing Care, 3, 001-013. https://doi.org/10.29328/journal.cjncp.100 1010

Anisa, N. R., Erika, K. A., \& Rachmawaty, R. (2018). Nurse's spiritual care competencies to patient with end stage breast cancer. Journal of Public Health,
7(4),

268-273.

https://doi.org/10.11591/ijphs.v7i4.14742

Atkinson, C. (2015). Islamic values and nursing practice in Kuwait. Journal of Holistic Nursing, 33(3), 195-204.

Bakir, E., Samancioglu, S., \& Kilic, S. P. (2017). Spiritual Experiences of Muslim Critical Care Nurses. Journal of Religion and Health, 56(6), 2118-2128. https://doi.org/10.1007/s10943-017-03824

Berman, A., Snyder, S., \& Frandsen, G. (2015). Kozier \&amp; Erb's fundamentals of nursing: concepts, process, and practice (10th ed.). Pearson.

Chen, J., Lin, Y., Yan, J., Wu, Y., \& Hu, R. (2018). The Effects of Spiritual Care on Quality of Life and Spiritual Well-Being Among Patients with Terminal Illness: A Systematic Review. Palliative Medicine, 32(7), 1167-1179. https://doi.org/10.1177/026921631877226 7

Dadfar, M., Bahrami, F., Noghabi, F. S., \& Askari, M. (2016). Relationship Between Religious Spiritual Well-Being and Death Anxiety in Iranian Elders. International Journal of Medical Research \& Health Sciences, 5, 283-287. Retrieved from www.jjmrhs.com

Dewi, I. P., \& Anugerah. (2020). Asuhan Keperawatan Spiritual Islam. (P. S. Aisyah, Ed.) (1st ed.). Bandung: Manggu.

Dewi, I. P., \& Widiyanti, A. T. (2018). Qur'anic Therapy (Islamic Bibliotherapy) To Improve Religious Coping In Hemodialysis Patient. Media Keperawatan Indonesia, 1(3), 12-17.

Dewi, R. R., \& Dewi, I. P. (2016). Persepsi perawat dalam pelaksanaan asuhan keperawatan spiritual muslim di RS Muhammadiyah Bandung. Jurnal Keperawatan Aisyiyah, 3(1), 91-106.

Estetika, N., \& Jannah, N. (2016). Pelaksanaan asuhan keperawatan spiritual di Rumah Sakit Banda Aceh. Retrieved January 1, 2019, from https://adoc.tips/pelaksanaanasuhan-keperawatan-spiritual-di-suaturumah-saki.html 
Frouzandeh, N., Aein, F., \& Noorian, C. (2015). Introducing a spiritual care training course and determining its effectiveness on nursing students' self-efficacy in providing spiritual care for the patients. Journal of Education and Health Promotion, 4(May), $34 . \quad$ https://doi.org/10.4103/22779531.157189

Hanin Hamjah, S., Shakirah Mat Akhir, N., Ismail, Z., Ismail, A., \& Mohd Arib, N. (2017). The application of ibadah (worship) in counseling: Its importance and implications to muslim clients. J Relig Health, 56, 1302-1310. https://doi.org/10.1007/s10943-015-01226

Heidari, A., \& Yoosefee, S. (2016). The Relationship between Spiritual Health and other Dimensions of Health: Presentation of a Model. Health, Spirituality and Medical Ethics (Vol. 3). Retrieved from http://jhsme.muq.ac.ir/article-1-102-en.pdf Inggriane Puspita Dewi, \& Siti Ulfah Rifa'atul Fitri. (2020). Pemanfaatan Seft Sebagai Modalitas Therapy Community (TC) Untuk Kesehatan Mental Dan Spiritual Pecandu Napza. Jurnal Pengabdian UntukMu NegeRI, 4(1), 88-94. https://doi.org/10.37859/jpumri.v4i1.1895

Jeihooni, K. A., \& Seyyed Hannan, K. (2016). Factors influencing poor nursing documentation from the perspective of nursing staff. International Journal of Medical Research \& Health Sciences, 5, 717-718. Retrieved from www.ijmrhs.com

Kemenkes RI. (2019). Profil Kesehatan Indonesia 2018. Jakarta. Retrieved from http://www.depkes.go.id/resources/downl oad/pusdatin/profil-kesehatanindonesia/Data-dan-Informasi_ProfilKesehatan-Indonesia-2018.pdf
Marzband, R., Hosseini, S. H., \& Hamzehgardeshi, Z. (2016). A concept analysis of spiritual care based on Islamic sources.

Religions. https://doi.org/10.3390/rel7060061

Nasr, S. H. (2013). Islamic Spirituality: Foundations. Islamic Spirituality: Foundations. https://doi.org/10.4324/9781315888200

Nurdina, Y., \& Putra, A. (2016). Hubungan pelayanan spiritual dengan kepuasan pasien di Rumah Sakit Meuraxa Kota Banda Aceh. Jurnal IImiah Mahasiswa Fakultas Keperawatan, 1(1).

Nurhakim, A. I., Dewi, I. P., \& Rohmah, N. (2018). Pengaruh terapi Qur'anic Healing terhadap penurunan tekanan darah pada lanjut usia penderita hipertensi. Jurnal Keperawatan Aisyiyah, 5(1), 7-15.

Paal, P., Roser, T., \& Frick, E. (2014). Developments in spiritual care education in German - Speaking countries. BMC Medical Education, 14(1). https://doi.org/10.1186/1472-6920-14-112

Pangerapan, D. T., Palandeng, O. E. L. I., \&Rattu, A. J. M. (2018). Hubungan Antara Mutu Pelayanan dengan Kepuasan Pasien Di Poliklinik Penyakit dalam Rumah Sakit Umum Gmim Pancaran Kasih Manado. JKK (Jurnal Kedokteran Klinik), 2(1), 9-18.

Sjattar, E. L., \& Hadju, V. (2019). Analisis hubungan kontak dan komunikasi perawat pada pelaksanaan keperawatan spiritual dengan kepuasan pasien. Jurnal IImiah Kesehatan Pencerah, 08(2), 131136.

Van-Leeuwen, R. (2016). Towards nursing competencies in spiritual care. Studies in Spirituality, 19(0), 249-289. https://doi.org/10.2143/sis.19.0.2043682 